\title{
ヒト $\operatorname{IgD}$ に関する研 究*
}

\author{
第 1 報 : $\operatorname{IgD}$ 精製法の確立と抗血清の作製について
}

\author{
荒川 正明 $* *$ ・榎本・博光**伊藤 喜久** \\ 櫻林郁之介**.河合＼cjkstart忠**
}

\begin{abstract}
Summary
A new method was established for a high yield of purified $\operatorname{IgD}$ by using ion exchange chromatography under the conditions where the IgD protein was not absorbed.

Despite the buffer containing $0.01 \mathrm{M} \varepsilon$-amino caproic acid was used to protect against proteolysis, spontaneous degradation of $\operatorname{IgD}$ occured during purification step at $4^{\circ} \mathrm{C}$. The molecular weight of this degradation fragment was about 123,000 daltons determined by SDS-PAGE. It was, therefore, probable that the fragments were $\mathrm{F}(\mathrm{ab})_{2} \delta$ or the dimer of $\mathrm{Fc} \delta$ and $\mathrm{Fab} \delta$.

For the study of the reactivity aginst Fab $\delta$ portion, specific rabbit anti-IgD antibody was prepared and compared with those supplied commercially. The results indicated that the latter did not show any reaction against $\mathrm{Fab} \delta$, suggesting that it may lack the antibody against $\mathrm{Fd} \delta$.

Key words : $\operatorname{IgD}$, purification, $\varepsilon$-amino caproic acid, spontaneous degradation, $\mathrm{Fc} \delta$ and $\mathrm{Fab} \delta$.
\end{abstract}

緒 言

1965年，Rowe らによって第 4 番目の免疫グロブリン として発見さ礼た $\operatorname{IgD}^{1)}$ は，B 細胞膜表面に多く存在 し2,3), ヒトの免疫応答に和けるとの役割が最近注目され てきている4). しかし，IgD の血清中濃度がきわめて微 量であること ${ }^{5,6)}$, 生体内酵素によって分解を起こしや すいことなどから，その分子構造や機能については未だ 不明な点が多い。また，このような IgD の諸性質は， その免疫学的測定法にも種々の影響を及ぼし，検体の保 存条件や標準物質なぞにより一層の規準化が望まれてい

る.われわれは，

1)このよらな IgD の諸性質を明らかにすること.

2）信頼性の高い測定法を確立すること.

3） IgD 測定の臨床的意義を明らかにすること. を目的として研究を進めているが，今回，骨髄腫患者血 清からの高純度な IgD 精製法を確立し，抗血清を作製 し，種々の検討を試みたので報告する.

\section{材料および方法}

1. IgD の単離精製法 (Table 1)

同一の $\operatorname{IgD}-\lambda$ 型骨髄腫患者血清を用いて以下に示す ような 2 種類の方法により精製を行った.

血清に飽和硫安を $45 \%$ になるように添加し沈殿物分画 を蒸留水で溶解し, Method 1 では $0.01 \mathrm{M}$ リン酸緩衝 液 (以下 $\mathrm{PB}$ と略), $\mathrm{pH} 8.0$ で, Method 2 はで $0.04 \mathrm{M}$ $\mathrm{PB}, \mathrm{pH} 8.0$ で透析後, 遠心分離・沪過して, 生じた沈 殿物を除去した. 次に, DEAE-Sephadex A-25 (Pharmacia 社）を用いたイオン交換 クロマトグラフィーを 行った. Method 1 では 0.01 M PB, pH 8.0.で平衡化 したカラム $(\phi 2.6 \mathrm{~cm} \times 30 \mathrm{~cm})$ 飞試料を吸着させ，カラ 厶内を上記緩衝液で十分洗浄後, $0.02 \mathrm{M}, 0.04 \mathrm{M}, 0.06$ $\mathrm{M} \mathrm{PB}, \mathrm{pH} 8.0$ にて, stepwise で IgD を溶出させて得 た. Method 2 では $0.04 \mathrm{M} \mathrm{PB}, \mathrm{pH} 8.0$ で Method 1 と同様にカラム内を平衡化し，試料を添加した．この条 件では試料中の IgD は吸着されない。次に，DEAE-

* Studies on human immunoglobulin D. I : Purification of IgD and preparation of antiserum.

** Masaaki Arakawa, Hiromitsu Enomoto, Yoshihisa Ito, Ikunosuke Sakurabayashi, Tadashi Kawai, 自治 医科大学臨床病理学教室.

（受付 1982年 3 月 1 日，受理 1982年5月27日） 
Table 1. Procedure for purification of $\operatorname{IgD}$.

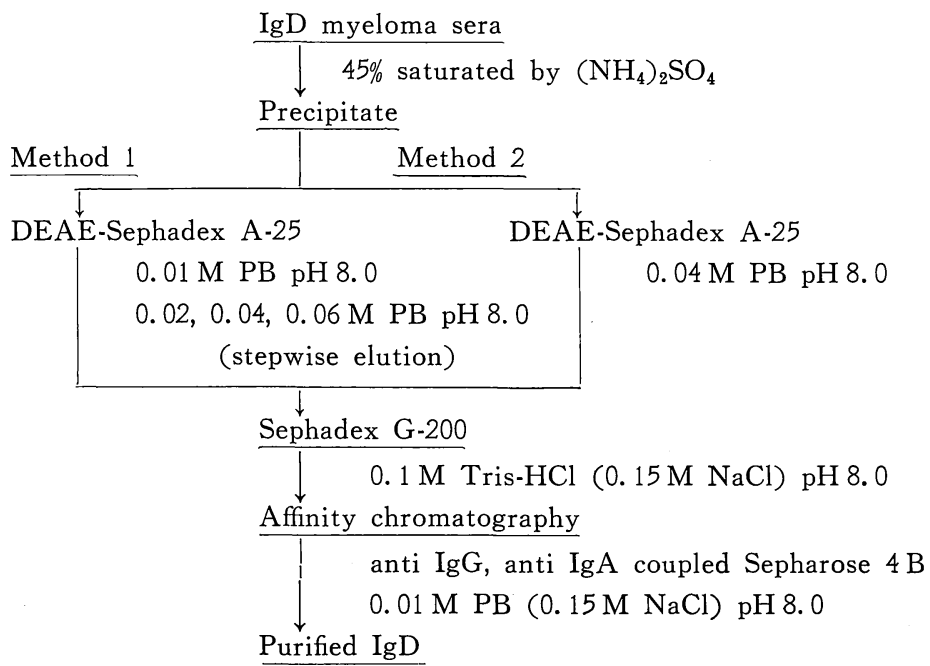

All buffers contained $0.01 \mathrm{M} \mathrm{EACA}$ and $0.05 \% \mathrm{NaN}_{3}$.

Sephadex A-25 カラムで溶出した IgD main 分画を Sephadex G-200 ( $\phi 2.6 \mathrm{~cm} \times 90 \mathrm{~cm})$ によりゲル汇過を 行った. この段階からは, Method 1, 2 とも同じ方法で ある.ゲル沪過に用いた緩衝液は $0.1 \mathrm{M}$ Tris- $\mathrm{HCl}$ (含 $0.15 \mathrm{M} \mathrm{NaCl}$ ) pH 8.0 である. さらに, ゲル沪過で溶 出した $\operatorname{IgD}$ main 分画を, 抗 $\operatorname{IgG}$, 抗 $\operatorname{IgA}$ を $\mathrm{BrCN}$ 活性化 Sepharose 4B に結合させた affinity column に 通し， IgG，IgA を吸着除去し， IgD を精製した。緩衝 液は $0.01 \mathrm{MPB}$ (含 $0.15 \mathrm{M} \mathrm{NaCl}$ ) pH8.0を用いた.

なお，精製に使用した緩衝液すべてに，0.01 M の $\varepsilon$ amino caproic acid (以下 EACA と略) と $0.05 \%$ の $\mathrm{NaN}_{3}$ を添加した。 また，精製 $\mathrm{IgD}$ の純度はディスク 電気泳動法 (Davis らの方法7)， $7.5 \%$ ポリアクリルア ミドゲルを使用）で，分子量は SDS-PAGE (WeberOsborn の方法8)，5\%ポリアクリルアミドゲルを使用） で検定した。

2. 自家製抗 $\operatorname{IgD}$ (以下抗 $\operatorname{IgD}$ と略) の作製法

Mehod 1 で精製した IgD $1 \mathrm{mg}$ をFreund's complete adjuvant (FCA) と等量混合し, ウサギの背部皮 下に免度し， 2 週間ごとに精製 IgD $0.5 \mathrm{mg}$ を追加免 疫して約 3 ケ月後に採血し抗血清を得た. この抗血清は $\mathrm{IgD}$ との反応以外に IgG との反応が認められたので, 人血清で吸収して特異抗血清を作製した。

\section{3. $\mathrm{Fc} \delta$ と $\mathrm{Fab} \delta$ の精製法}

精製 $\operatorname{IgD} 0.01 \mathrm{M} \mathrm{PB}, \mathrm{pH} 8.0$ 飞て透析後, trypsin (Sigma 社) を IgD の $1 / 100$ 量添加し， $37^{\circ} \mathrm{C} て ゙ 2$ 分間 incubate し，ただちに trypsin soybean inhibitor (Si- gma 社)を $\operatorname{IgD}$ の $1 / 50$ 量添加し, 反応を止めた ${ }^{9)}$. 得られた試料を，DEAE-Sepharose CL-6 B を $0.01 \mathrm{M}$ $\mathrm{PB}, \mathrm{pH} 8.0$ (含 $0.01 \mathrm{MEACA}$ ) で平衡化したカラムた 添加した. この条件で, $\mathrm{tFab} \delta$ (trypsin 処理で得られ た $\mathrm{Fab} \delta$ ) は吸着されず通過する．カラム内を上記緩衝 液で十分洗浄後, $0.01 \mathrm{MPB}$ (含 $0.15 \mathrm{M} \mathrm{NaCl}, 0.01$ M EACA) $\mathrm{pH} 8.0$ にて $\mathrm{tF} \delta$ (trypsin 処理で得られた $\mathrm{Fc} \delta)$ を溶出させて得た. 次に, $\mathrm{tFab} \delta$ main 分画, $\mathrm{tFc} \delta$ main 分画を各々 Sephadex G-200 カラム $(\phi 2.6$ $\mathrm{cm} \times 90 \mathrm{~cm})$ にてゲル沪過を行い, $\mathrm{tFab} \delta$ 拈よび $\mathrm{tFc} \delta$ を 精製した，緩衝液は $0.01 \mathrm{M} \mathrm{PB}$ (含 $0.15 \mathrm{M} \mathrm{NaCl}, 0.01$ MEACA）pH 8.0 を用いた.

な拈，精製に使用した緩衝液すべてに0.05\%の $\mathrm{NaN}_{3}$ を添加した.

\section{4. 免疫化学的分析}

精製 $\mathrm{IgD}, \mathrm{tFab} \delta, \mathrm{tF} \delta$ 括よび抗 $\operatorname{IgD}$ の分析を, 免 疫電気泳動法拈よび Ouchterlony 法にて行った。分析 に使用した抗血清は，Dako 社製（抗 $\delta$, 抗 $\gamma$, 抗 $\alpha$, 抗 $\mu$ ，抗 $\lambda$ ，抗 $\kappa$ ，抗 $\alpha_{2}$-m, 抗 $\mathrm{Tf}$ ，抗七卜全血清，抗 $\mathrm{C}_{3}$, 抗 $\beta$-Lipo）扣よび Behring 社製（抗 $\delta$, 抗 $\mathrm{Hpt}$ ) である.また， IgD の定量は MBL 社製プレート (SRID 法）を用いて行った. 免疫電気泳動法は Grabar-Williams の方法 ${ }^{10}$ に従って行い，Ouchterlony 法 ${ }^{11)}$ では1\% agar（Oxoid 社）ゲル板を用いて行った. 
Table 2. The recovery of $\operatorname{IgD}(\%)$ in each step

\begin{tabular}{c|c|c}
\hline Purification step & Method 1 & Method 2 \\
\hline $45 \%\left(\mathrm{NH}_{4}\right)_{2} \mathrm{SO}_{4}$ & $81.0 \%$ & $71.4 \%$ \\
DEAE-Sephadex A-25 & $36.8 \%$ & $59.1 \%$ \\
$\begin{array}{c}\downarrow \\
\text { Sephadex G-200 }\end{array}$ & $11.8 \%$ & $39.4 \%$ \\
Affinity chromatography & $5.6 \%$ & $34.3 \%$ \\
\hline
\end{tabular}

同一血清を出発材料として，イオン交換クロマトグラ フィーでの処理を異にした精製法 Method 1 と Method 2, 各々の方法で精製された IgD の収率およびその性状 について比較検討を行った.

\section{1) 収率 (Table 2)}

精製材料に用いた血清に含まれている IgD 量を SR ID 法で測定し，その測定值を $100 \%$ とて計算した.イ オン交換クロマトグラフィー処理後で, $\operatorname{IgD}$ の収率は Method 1 では約 37\%, Method 2 では約 59\%で，最 終的に affinity カラムクロマトグラフィー処理後, 精製 された IgD の収率は, Method 1 では約 6\%, Method 2 では約 34\%亡明らかに Method 2 の方が良好な収率 を示した。

2）免疫電気泳動法による分析（Fig. 1)

Method 1 扎よび Method 2 で精製された IgDを各

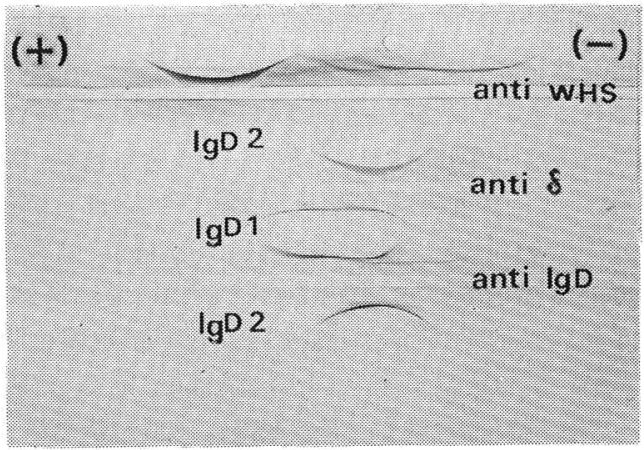

Fig. 1. Immunoelectrophoretic patterns of purified $\operatorname{IgD} 1$ and $\operatorname{IgD} 2$.

$\operatorname{IgD} 1$ : purified by Method 1, $\operatorname{IgD} 2$ : purified by Method 2 .

各免疫電気泳動を行い比較検討すると, Method 2 で精 製された $\operatorname{IgD}$ は抗 $\delta$ と 1 本の沈降線を示し, 抗 $\operatorname{IgD}$ と の反応でやや陰極側にも51本沈降線が認められた.

Method 1 で精製された IgD は抗 $\delta$ との反応で沈降線 は1本であるが，陽極側に延びて孤を形成して扣り，抗 $\operatorname{IgD}$ と反応では, さらに陰極側に 1 本沈降線が認めら れた.

3）ディスク電気泳動法拈よび SDS-PAGE 法による 分析 (Fig. 2)
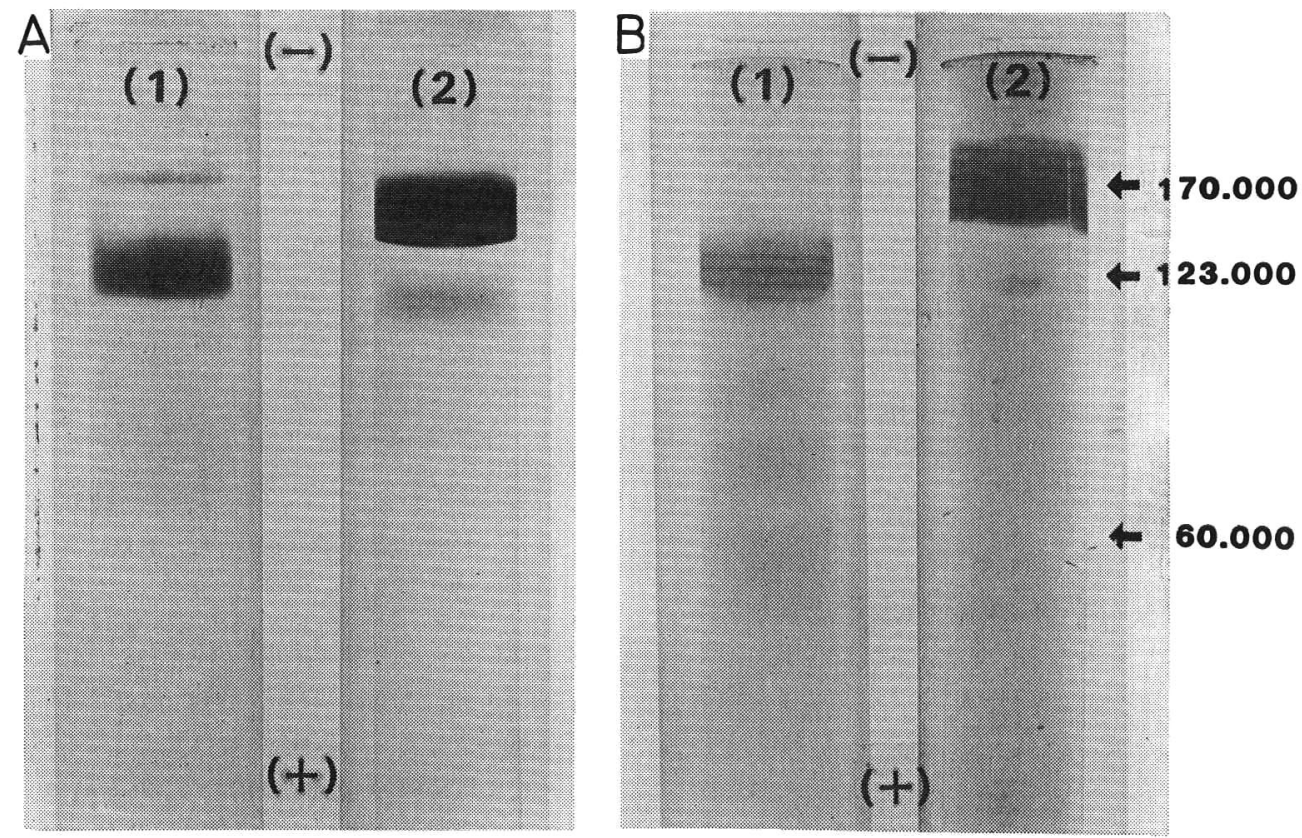

Fig. 2. Disc electrophoretic patterns (A) and SDS-PAGE patterns (B) of purified IgD. (1): purified by Method 1, (2): purified by Method 2. 
Method 1 および Method 2 で精製された IgD を各 々ディスク電気泳動拈よび SDS-PAGEを行い比較検討 すると,ディスク電気泳動において，各々のバンドは 2 本であるが，main バンドの位置が異なって扣り， Method 1 で精製された IgD の main バンドはより陽極 側で, Method 2 で精製された $\operatorname{IgD} の$ main バンドは より陰極側であった，SDS-PAGE に招いて，Method 1 で精製された $\operatorname{IgD}$ の main は分子量約 12,300 で, Method 2 で精製された IgD の main は分子量約 170,000であった。 また，分子量約 60,000を示すバンド がわずかながら認められた。
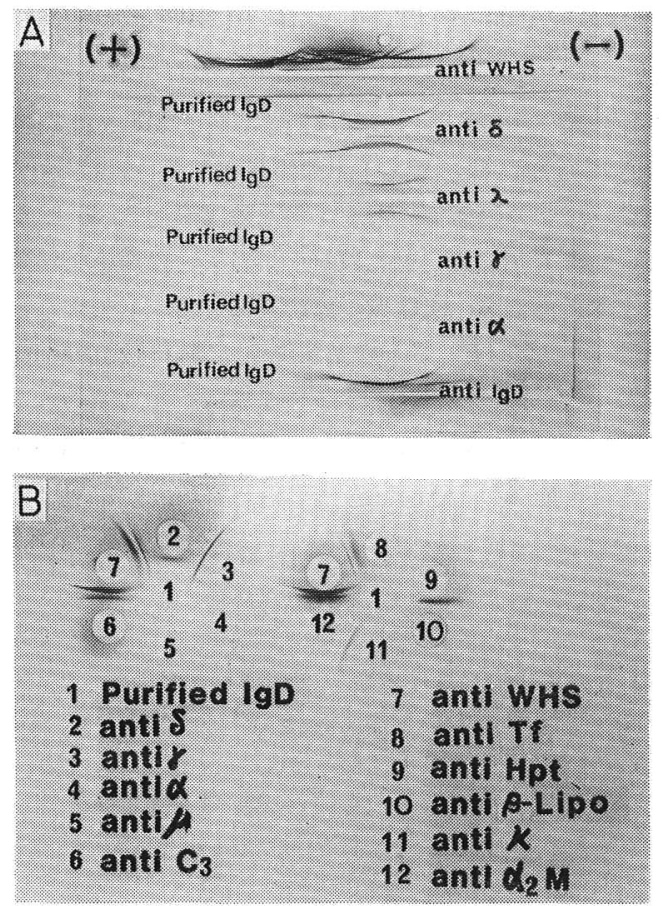

Fig. 3. Immunoelectrophoretic patterns (A) tnd Ouchterlony immunodiffusion analyses (B) of purified $\operatorname{IgD}$.

\section{2. 精製 IgD の分析 (Fig. 3)}

免疫電気泳動法抒よび macro Ouchterlony 法による 分析で, 精製 $\operatorname{IgD}$ と抗 $\gamma$, 抗 $\alpha$, 抗 $\mu$, 抗 $\mathrm{C}_{3}$, 抗 $\alpha_{2}-\mathrm{m}$, 抗 Tf, 抗 Hpt, 抗 $\kappa$, 抗 $\beta$-Lipo, および抗ヒト全血清

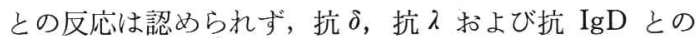
又反応が認められた，免疫電気泳動での抗 $\lambda$ との反応で 染色後は Fig. 3-a に示したように沈降線がはっきり認 められるが，染色前は沈降線は認められず，染色後に認 められた沈降線と同じ位置に透明な line が認められた.
また，抗 IgD との反応で抗 $\delta$ との反応では認められな かった沈降線が陰極側に 1 本認められた. ディスク電気 泳動で精製 $\operatorname{IgD}$ は2 本のバンドを示した.

3. 自家製抗血清 (抗 $\operatorname{Ig} D$ ) の分析

ウサギを採血して得た特異抗血清は, Fig. 3-A に示し たように免疫電気泳動に拈いて, 精製 IgD との反応で 2 本の沈降線を形成した。 なた，データは省略したが， 正常人血清との反応は認められなかった。 マクロオクテ ロニー法で, 抗 $\operatorname{IgD}$ は $\operatorname{IgG}, \operatorname{Ig} \mathrm{A}, \operatorname{Ig} M$, および $\lambda$ 型 Bence Jones protein と反応せず，また精製 $\operatorname{IgD} と の ~$ 反応で認められた沈降線は, 市販抗血清抗 $\delta$ との沈降線 と完全に融合した. (Fig. 4)

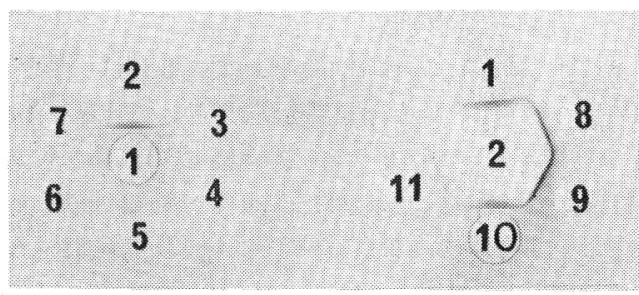

Fig. 4. Ouchterlony immunodiffusion analyses of anti $\mathrm{IgD}$.

1: anti $\operatorname{IgD}$ Lot-1, 2 : purified $\operatorname{IgD}$ by Method 1, 3: purified $\operatorname{IgG}, 4:$ purified $\operatorname{Ig} A, 5:$ purified IgM, $6:$ purified BJ, $7:$ NHS, $8:$ anti IgD Lot-2, $9:$ anti IgD Lot-3, $10:$ anti $\delta$ (Dako), 11 : anti $\delta$ (Behring).

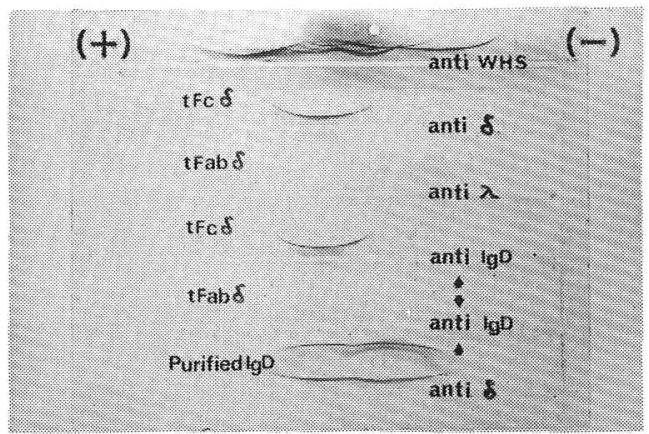

Fig. 5. Immunoelectrophoretic patterns of $\mathrm{tFc} \delta$ and $\mathrm{tFab} \delta$

4. $\mathrm{tFc} \delta$ 执よび $\mathrm{tFab} \delta$ の分析 (Fig. 5)

Trypsin 処理を行って得た $\mathrm{tF} c \delta$ と $\mathrm{tFab} \delta$ を, 免疫 電気泳動法で分析した. $\mathrm{tFc} \delta$ は抗 $\delta$ 打よび抗 $\mathrm{IgD}$ と反 応し, その沈降線の位置は, 精製 $\operatorname{IgD}$ と抗 $\delta$ 打よび抗 $\mathrm{IgD}$ との反応で認められる沈降線の陽極側に延びた沈降 線と泀ぼ同じ位置である. $\mathrm{tFab} \delta$ は抗 $\mathrm{IgD}$ 扣よび抗 $\lambda$ と反応し, その沈降線の位置は精製 $\operatorname{IgD}$ と抗 $\operatorname{IgD}$ と反 
応で認められる, より陰極側の沈降線とほぼ同じ位置で あった (Fig. 5 の矢印).

\section{考察}

以上述べた結果より，まず $\operatorname{IgD}$ 精製法に関しては, イオン交換クロマトグラフィー処理でカラムに $\operatorname{IgD} を$ 吸着させない Method 2 の方が吸着させて後で溶出さ せて得る Method 1 より明らかに収率および精製 $\mathrm{IgD}$ の性状の点で良好な結果を示した。また，各精製段階に 扒いて, IgD 量測定と同時に F. Lowry 法に上る蛋白 量を測定しており， $\mathrm{IgD}$ の純度を比較すると,イオン交 換クロマトグラフィー処理後は Method 1 の方が高い 純度を示したが，絶対量は明らかに Method 2 の方が 多かった. 最終的に精製された $\operatorname{IgD}$ の純度はどちらも ほぼ 100\%に近かった．従って，IgD の精製を行ら場 合は，イオン交換クロマトグラフィーの段階で IgD を 吸着させず通過させることがより良い方法であると考兄 られる。しかし，IgD 骨髄腫患者血清中に含をれている $\mathrm{IgD}$ は個人によりその電気的移動度が異なるので，今 回は 0.04M PBを用いて IgD を通過させたが，各々の 血清の少量をイオン交換クロマトグラフィー処理して, それぞれに適合した緩衝液を選び出す必要があると考え られる。

Method 1 で精製された IgD の免疫電気泳動で抗 IgD との反応で認められる陽極側に延びた沈降線と，陰極側 に認められるもら 1 本の沈降線は, 精製 IgD を trypsin 処理して得た $\mathrm{tFc} \delta$ と $\mathrm{tFab} \delta$ の免疫電気泳動に执ける 抗 $\mathrm{IgD}$ との反応から推測して, 各々 $\mathrm{F} \mathrm{c} \delta$ 㧊よび $\mathrm{Fab} \delta$ が抗 IgD と反応して形成された沈降線であると考兄ら れる12,13)。抗 IgD は IgG, IgA, IgM および $\lambda$ 型 $\mathrm{Be}$ nce Jones protein との反応は示さないことから L-chain に対する抗体は含んで扬らず， $\mathrm{tFab} \delta$ との反応は抗 $\mathrm{Fd} \delta$ によるものと考光られる。な拉，データは省略し たが，ほかに 2 種類の $\lambda$ 型 Bence Jones protein と抗 IgD との反応は, マクロオクテロニー法で認められな かった. 一方, 市販の抗血清抗 $\delta$ は $\mathrm{tFab} \delta$ と反応を示 さないことから， Fd $\delta$ に対する抗体がごく微量である

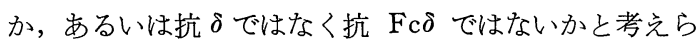
れる. また，Fig. 1 で示したように, Method 1 で精 製された $\operatorname{IgD}$ と抗 $\operatorname{IgD}$ との反応で認められる2本の 沈降線は交差しているようである．陰極側の沈降線は抗 $\mathrm{Fd} \delta$ によって形成された沈降線と考兄られるため, 完 全 $\operatorname{IgD}$ と抗 $\operatorname{IgD}$ との反応で認められる沈降線と 1 部 融合するはずであるが, 交差していることから, 完全
IgD の $\mathrm{Fd}$ region が隠されて, 抗 $\mathrm{Fd} \delta$ と反応しない のではないかとも考觉らる。

精製 IgD の免疫電気泳動に护ける抗 $\lambda$ との反応で認 められる透明な line は, $\operatorname{IgD}$ と抗入との反応でしばし ば認められる clear line（または phantom line）であ ると推測される ${ }^{14)}$. また精製 IgD のディスク電気泳動 で認められる 2 本の蛋白帯は, ゲルを切り出した後, 抗 $\delta$ による分析からどちらも IgD であることを確認して 扣り, そのらち 1 本 (陽極側) は $\operatorname{IgD}$ の精製保存中に 自然分解15 17)で生じた fragment であると考兄られる. この fragment は, 上記免疫電気泳動に括ける抗 $\operatorname{IgD}$ との反応で認められる陽極側扣よび陰極側の沈降線を形 成する $\mathrm{F} \mathrm{c} \delta$ 扤よび $\mathrm{Fab} \delta$ であると考えられるが， SDSPAGE による分析から，この fragment の分子量は約 123,000であり，ごくわずかに分子量約 60,000 の蛋白帯 も認められるが， $\mathrm{Fc} \delta$ および $\mathrm{Fab} \delta$ が各々 2 量体を形 成しているか，さらには $\mathrm{F}(\mathrm{ab})_{2} \delta$ も含まれているので はないかと推測される。しかし，Method 2 で精製され た $\operatorname{IgD}$ の免疫電気泳動で，抗 $\operatorname{IgD}$ との反応で認めら れるやや陰極側の沈降線は, 精製を開始する前の血清に すでに認められていることから，Method 2 の精製過程 における分解はわずかであると推測される.

$\operatorname{IgD}$ の精製保存に使用した緩衝液にはすべて $0.01 \mathrm{M}$ の $\mathrm{EACA}$ が含まれているが，この条件では IgD の自 然分解を完全に抽えることはできず，特にイオン交換ク ロマトグラフィー処理で IgD を吸着させた場合は，ほ とんど効果がなかった。しかし，0.01 M の EACA 添 加により, 保存中の $\operatorname{IgD}$ の分解がごくわずかであるこ とから, この時に起こる $\operatorname{IgD}$ の分解は, $\operatorname{IgD}$ が吸着さ れることによりプロテアーゼの作用をより受けやすくな ったとも考兄られる゙，IgDが吸着されることだけで分 解が起こるのではないかと考兄れる. EACA 以外の inhibitor については今後検討していく予定である.

\section{ま と め}

$\operatorname{IgD}$ の精製法に関しては, これまで種々の報告がなさ

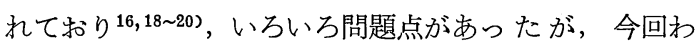
れわれは高純度でかつ収率の高い IgD の精製法を確立 した. 精製に括いて，イオン交換クロマトグラフィー処 理を行う場合は, $\operatorname{IgD}$ 自体を吸着させず通過させるこ とが最良の方法である。しかし， IgD の自然分解は 0.01 $\mathrm{M}$ の $\mathrm{EACA}$ を添加しても徐々にではあるが起こって 打り， $\mathrm{F}(\mathrm{ab})_{2} \delta$ または $\mathrm{F} \mathrm{c} \delta$ 拉よび $\mathrm{Fab} \delta$ の 2 量体で ある fragment が生じてくると推測される。 また，市販 
の抗血清抗 $\delta$ は Fab $\delta$ との反応を示さないことから， $\mathrm{Fd} \delta$ に対する抗体がきわめて微量であると推測される。

\section{文献}

1) Rowe, D.S. and Fahey, J.L. : J. Exp. Med., $121: 171,1965$.

2) VanBoxel, J.A. et al. : J. Immunol., 109 : 648, 1972.

3) Melcher, U. et al. : J. Exp. Med., $140: 1427$, 1974.

4) Rowe, D.S. et al. : J. Exp. Med., 138:965, 1973.

5) Rowe, D.S. and Fahey, J.L.: J. Exp. Med., $121: 185,1965$.

6) Rowe, D.S. et al. : Clin. Exp. Immunol., 3 : 477, 1968.

7) Davis, B.J. : Ann. N.Y. Acad. Sci., 121 : 404, 1964.

8) Weber, K. and Osborn, M. : J. Biol. Chem., $244: 4406,1969$.

9) Shinoda, T. et al. : Proc. Natl. Acad. Sci. USA., 78 : 785, 1981.
10) Graber, P. and Williams, C. A. : Biochim. Biophys. Acta, 10:193, 1953.

11) Ouchterlony, O. : Handbook of Experimental Immunology. Blackwell Scientific Publications, Oxford, 1967.

12) Griffiths, R.W. and Gleich, G. J. : J. Biol. Chem., 247 : 4543, 1972.

13) Jefferis, R. and Mathews, J.B. : Immunochemistry, $14: 171,1977$.

14) Spiegelberg, H. L. : Immunol. Rev., $37: 3$, 1977.

15) Fahey, J.L. et al. : Am. J. Med., $45: 373$, 1968.

16) Rowe, D.S. et al.: Immunochemistry, 6 : 437, 1963.

17) Goyert, S.M. et al. : J. Immunol., $118: 2138$, 1977.

18) Jefferis, R. : J. Immunol. Methods, $9: 231$, 1976.

19) Spiegelberg, H.L. et al. : Biochem., $9: 2115$, 1970.

20) Lin, L-C. and Putnam, F. W. : Proc. Natl. Acad. Sci. USA., 76 : 6572, 1972. 